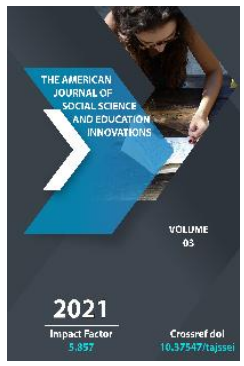

\title{
Problems And Solutions Of Teaching In Credit-Module System In Higher Education Institutions
}

\author{
Rasulov Inom Muydinovich \\ Head Of Department Distance Education Kokand State Pedagogical Institute Named After Muqimi, \\ Uzbekistan
}

Journal Website:

http://usajournalshub.c

om/index,php/tajssei

Copyright: Original content from this work may be used under the terms of the creative commons attributes 4.0 licence.

\section{ABSTRACT}

This article, which is proposed, is aimed at covering the implementation of the credit - module system in the educational practice of the Higher education of Uzbekistan on the basis of experiments of developed countries and, in other words, the implementation of this system in the field of computer science education. First of all, we need to clarify the concepts that will be discussed.

\section{KEYWORDS}

Credit - module system, education, distance learning, educational practice, development, computer science, ICT.

\section{INTRODUCTION}

The credit-module system is a system aimed at Independent Education, which determines the creative mastering of knowledge on the basis of individuality, the choice of the educational path with a strict definition of the educational process and the volume of knowledge in the 
case of credit. This system is now formed from a combination of two - module and credit teaching technologies, which are generally established in the educational system of developed countries, sufficiently justified in time trials and differ from each other, but mutually complementary. After all, the British philosopher Francis Bacon, who lived in the Middle Ages, said: the main key to a strong conflict resolution is a logical analysis of each terminology in the problem. While being able to give them an understanding of the scan to the rest, it solves the problem in advance.

The module is a separate educational science (or part of it), which includes information on relevant knowledge and professional aspects. The module system of teaching concludes with the appropriate type of knowledge, skills and competency control which is formed as a result of the student's learning of the science program. For example, current, intermediate and final control types are conducted to ensure that the level of knowledge and mastering of students is in compliance with state educational standards.

Modular training means orderly training. In this educational material can be taught in the volume of one training session, at the level of one subject or another department of the subject, and sometimes in a large part of the educational science, that is, in the style of blocks, says the head of the educational methodological

Modules primarily serve to effectively understand concepts, rules, theories, laws that relate to educational content and the laws that represent a common link between them. In modular education, the educator organizes, manages, advises, examines the process of mastering the listener. The student will be directed towards independent education towards the oriented subject.

\section{MATERIALS AND METHODS.}

The academic credit system, however, is a standardized assessment system that can determine whether the student will acquire effective knowledge in the institution of higher learning. The loan is made up of the time (hours) by the student to carry out the corresponding educational work. Each module has an independent credit score. The composition of the loan of a higher education institution independently determines the number of loans on each module, as well as the total number of loans that must be collected by the student to complete each course and the period of study in general. Another specific aspect of the academic credit system is that it conforms to international general education standards and the problems of adoption of documents on education are the proportion of curricula that take into account world trends. Students will have the opportunity to freely enter the higher education education level of foreign countries, Bachelor's and master's graduates will all have the right to employment in the state.

Why is it necessary to introduce a credit module system in the educational practice of Uzbekistan Higher education?

We find the answer to this question by showing the visible shortcomings of our traditional system, which has been used in practice so far in the activities of the Higher education of Uzbekistan.

- Failure to meet the requirements of the current operational information age of the 
traditional system, which has been used in practice so far in the activities of the Higher education of Uzbekistan;

- The fact that students remain mostly listeners in the Universities of Uzbekistan, as a result of which the personnel who have reached the slowness of practice are not able to give good results in the fields;

- The abundance of gaps in the evaluation system, and as a result, the root cause of corruption in the evaluation processes;

- The silence of the student's novelty. That is, in this system, the student is assigned a task, while the student performs it and thereby receives an assessment. Less emphasis is placed on the creative, independent work of the student;

- The most important thing is that this system is not compatible with the world's developed education systems. This is the main reason why we are not ready to compete with them.

In such conditions, Uzbekistan has chosen a credit - module system based on the world experience for a strong reform of the Higher education's activities, their inclusion in the ranks of the world's prestigious universities, the development of free and creative education, the implementation of quality education in accordance with world standards.

So, what work has been done in the education system of Uzbekistan in this regard?

For example, if the medical higher education institutions of our country have been studying since 2013, since 2016-2017 academic year at the Tashkent State University of Law on the basis of the module system of student education, the decree № PD-5847 of the president of the Republic of Uzbekistan "on approval of the concept of development of the higher education system - the task of transferring issues to this system of the stage was laid. According to this, from 2018-2019, the Tashkent University of Information Technologies named after Muhammad al - Khwarizmi switched to the credit-module system. At the same time, the number of $\mathrm{HEl}$ with the introduction of the credit-module system is planned to be delivered from 2 to 85 units. The number of non - state-private partnership-based HEI will reach 35. It is also emphasized in the decree on the replacement of theory with practical skills. At us now up to 40 percent of education is allocated for independent education, according to the consortium, this figure will reach 60 percent by 2030 year [3].

Now, I want to put a question that will reveal the main essence of our article. That is why it is necessary to introduce this system into the teaching of Computer Science.

As we all know, the disciplines that teach computer science require strong thinking and thinking. Teaching these subjects, however, is a more complicated process than teaching other field subjects. The introduction of credit - module system in the universities for the teaching and learning of these subjects significantly increases the effectiveness of Education, provides a basis for the application of computer science to practice. It allows higher education institutions teaching the Informatics sector in Uzbekistan to establish cooperation with the prestigious information universities of the world scale. 


\section{RESULT AND DISCUSSION}

What benefits does the transition to a credit module system provide to students in the field of informatics:

First, academic mobility - students will be able to transfer their studies to any suitable higher education without difficulty while maintaining their credit. It does not matter whether it is a world higher education or any other higher education in our country. Just, since the student loan to the student loan will reach the download threshold.

Secondly, students are given the choice of teacher. Through this, academic communication between the teacher and the student is ensured.

Third, students will be able to choose the subjects according to their desires. Of course, in this place there are also subjects that must be studied necessarily (specialist), but the student can independently determine the subjects of choice. This is the same provision for students in the field of Informatics. The reason is that this gives them enough time to perfectly study specialist subjects.

From scratch, students are allowed to create the opportunity to independently formulate the educational program and ensure transparency of the assessments to be made. This will ensure that corruption in the self education system is eradicated.

In contrast to the current system of education, the credit system will include non-compulsory subjects of selection and the student's personal timetable. Students will not be expelled from study or will stay from the course to the course. In which subject cannot collect the established credits, there will be a re-reading and re-examination of the same subject itself. Re-reading includes lectures, laboratories and practical classes, which are conducted from the first to the last lesson. Rereading paid. Its loan amount is calculated from the amount of the contract. And the Diploma of higher education is issued only after the meeting of the specified credits. At the end of the semester, 50 percent of the students ' grades are put by the science teacher, 50 percent by the management of the Higher education. That is, during one semester, professors and teachers evaluate the work of intermediate control, home tasks and practical training (laboratory). The final control is taken by the management of the $\mathrm{HEI}$. It is not attended by a teacher - professor. According to experts, in order to collect credits, students are required to attend classes, perform the given tasks on time, demonstrate their level of knowledge [4].

What kind of work should be carried out in order to transfer $\mathrm{HEl}$ of Uzbekistan to the credit - module system?

- First of all, for this purpose, the development of a regulation on measures to radically improve and improve the efficiency of the personnel training system in the universities developed by the Ministry of Higher Education for each of the universities.

- And on this basis, to develop a systematic program of training, proceeding from the practice of foreign universities in order to ensure the intensity of Education. 
- One of the biggest advantages of a creditmodule system is the introduction of science - based reduction in all HEl.

- For independent work, homework and laboratory assignments given to the student, to ensure the creation of a special site by the Higher education.

On this site, students download tasks in the given order, while the teacher verbally protects it. In this student's rating is determined by both the online and the instructor's deadline. On time, independent work and home tasks are not evaluated by students who do not upload them to the site. There is no re-delivery in this system. It can only be re-read.

To organize control and test assignments based on world standards at the end of each semester for students in the field of Informatics and to organize the strengthening of students' knowledge based on them.

This ensures that our students are able to meet the world standards of their level of knowledge.
Special mathematical assistive programs (MATlab, MATHcad, geogebra...) to teach the skills of using them and to create conditions for their wide use in practice.

This will serve them as a very great assistant in the rapid execution of calculations from the point of view of science and the broader formation of their mathematical imagination.

Provide a wide range of library resources with both print and electronic forms for all $\mathrm{HEl}$.

Of course, we need enough time for our students to adapt to such a system. Preparing them for this is first of all the task of pedagogical teachers. Therefore, in order to formulate such a system, it is necessary, first of all, to provide universities with professional and competent teachers. 


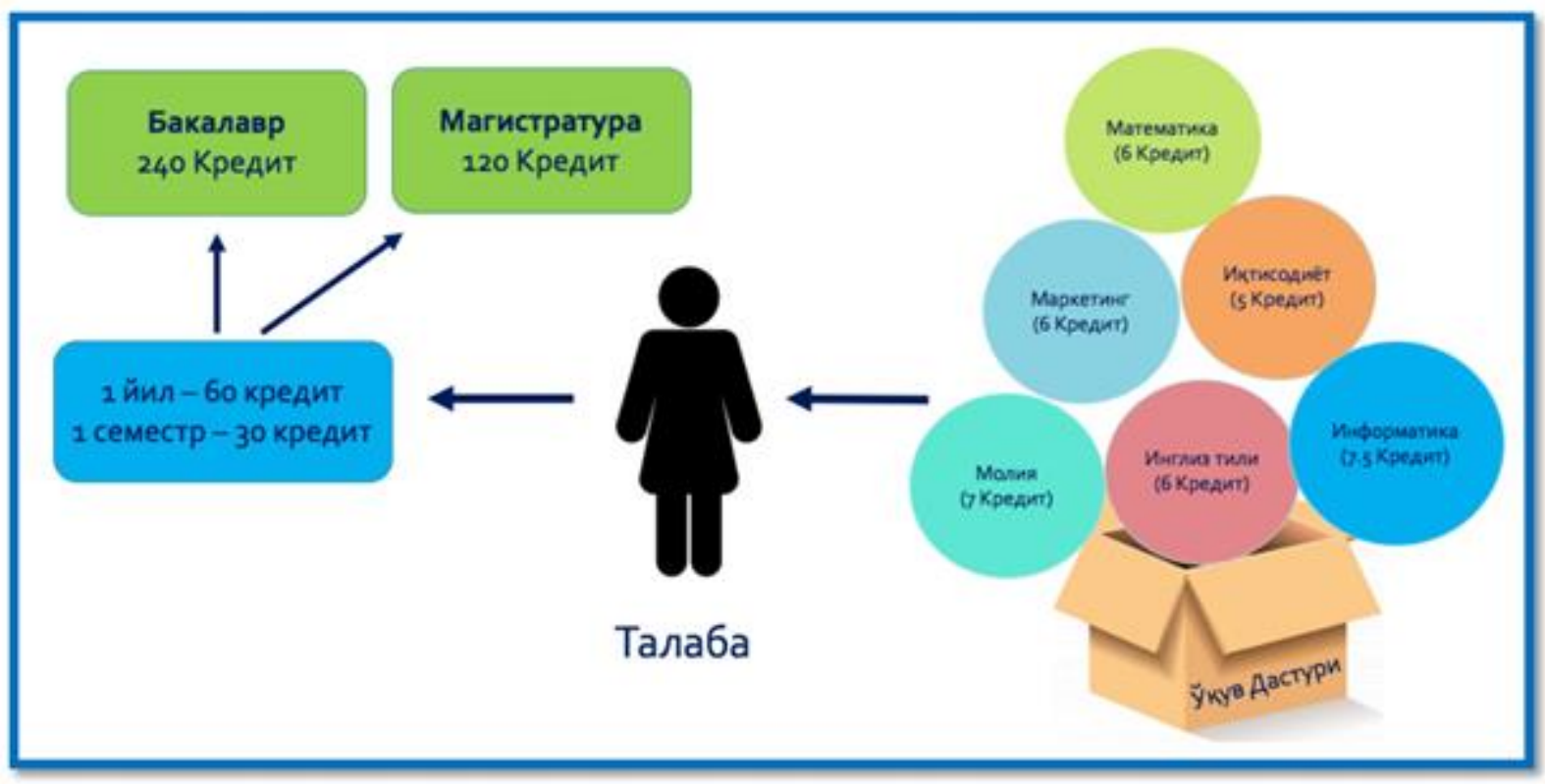

Reading load on the credit-module system

\section{CONCLUSION}

At the same time, the educational credit module system requires consideration of the principles of the organization of the educational process, control over the knowledge of students, material stimulation of the composition of teachers - professors of higher educational institutions and improvement of the right to work. In addition, it is important that students are provided with instructional materials and materials, comply with applicable standards educational credit system requirements, have a personal press center equipped with modern facilities and copywriting techniques. I am sure that the introduction of such a system into the education system of Uzbekistan will make a big turn on the path of development of all spheres of our country. Already educated and creative personnel, which have reached higher education, are the foundation of the future of our country.

\section{REFERENCES}

1. Decree of the president of the Republic of Uzbekistan "on approval of the concept of development of the higher education system of the Republic of Uzbekistan until 2030" № PF-5349.

2. Farxodjonova N. F., Abdurahimov V. A. MODERN TECHNOLOGIES OF STUDENTS TRAINING IN HIGHER EDUCATION //HAYKA И ТЕХНИКА. МИРОВЫЕ ИССЛЕДОВАНИЯ. - 2020. - C. 5-7.

3. Karimbekov S. V XXI Veke of Uzbekistan: obuchenie $\mathrm{S}$ ispolzavaniem system kreditav. Prospect razvitiya visshego obrozovaniya №3.Tashkent 2015. 115-P.

4. Sodirjonov, M. M. (2020). EDUCATION AS THE MOST IMPORTANT FACTOR OF HUMAN CAPITAL DEVELOPMENT. Theoretical \& Applied Science, (4), 901-905.

5. M. Tajiyev Mamadaliyev K. Khurramov A. Role of credit system in the development of higher education system of developed 
foreign countries. Prospects of development of higher education: total №3. -Tashkent 2015. 52-p.

6. Qizi F. N. F. Modernization Of Uzbek Language And National-Spiritual Heritage In National Culture //The American Journal of Social Science and Education Innovations. - 2021. - T. 3. - №. 01. - C. 585594.

7. Farxodjonova N. F. Modernization and integration: social-philosophical analysis. Rol'nauki $v$ formirovanii sovremennoj virtual'noj real'nosti. - 2019 .

8. Mahamadaminovich, S. M. (2020). THE ESSENCE OF SOCIAL CAPITAL CONSEQENCES AND THEIR INFLUENCES TO THE MODERN SOCIETY. Вестник науки и образования, (2-2 (80)). 